\title{
Underwood Family Sonoran Landscape Laboratory Methods
}

Firm Liaisons:

Todd M. Briggs

Project Landscape Architect

Ten Eyck Landscape Architects

Christine Ten Eyck, FASLA

President

Ten Eyck Landscape Architects

This case study was produced in 2010 as part of the Landscape Architecture Foundation's Landscape Performance Series pilot. Firms submitted their projects, and LAF staff worked with firm representatives to document the project and its environmental, social, and economic benefits.

To cite:

Landscape Architecture Foundation. "Underwood Family Sonoran Landscape Laboratory." Landscape Performance Series. Landscape Architecture Foundation, 2010.

https://doi.org/10.31353/cs1481

The full case study can be found at:

https://landscapeperformance.org/case-study-briefs/underwood-sonoran-landscape-laboratory 


\section{Underwood Family Sonoran Landscape Laboratory Methodology for Landscape Performance Benefits}

\section{- Reclaimed 1.2 acres of a former university parking lot to create a viable Sonoran Desert landscape.}

The 1.2 acres was defined as the limit of work agreed to by the University of Arizona for the purposes of the expansion of the College of Architecture and Landscape Architecture (CALA) which included the building expansion footprint, modifications to the existing parking lot, and the introduction of the landscape and outdoor pedestrian components. According to Ron Stoltz, Professor in the School of Landscape Architecture and Planning at the University of Arizona (personal correspondence, 2011), all five biomes of the Sonoran desert landscape are now well developed, with two fish and one frog species that are listed as endangered or threatened.

- Reduces potable water use for irrigation during the initial 5-year desert establishment period by $87 \%$ or 280,000 gallons annually. After the establishment period, the need for potable water in irrigation should be eliminated.

The establishment period is an estimation of time required to ensure the introduced native vegetation is adequately established through the use of a regular irrigation program prior to slowly reducing water provisions to the planting. The overall reduction in potable water consumption of $87 \%$ is based upon calculating overall water needs of the landscape as compared to the potential capture and storage of alternative non-potable water sources. These sources and their quantities are as follows:

\author{
Water Source \\ Roof Run-Off (Tucson average rainfall) \\ HVAC Condensate \\ Well Blow-off \\ Grey Water (sinks/drinking fountains) \\ Total Water Harvested Annually: \\ Total Landscape Water Required Annually: \\ Potable Water Required Annually: \\ $\%$ Reduction of Potable Water Use:
}

\author{
Gallons Captured Annually \\ 84,000 gallons \\ 95,000 gallons \\ 45,000 gallons \\ 19,000 gallons \\ 243,000 gallons \\ 280,310 gallons \\ 37,310 gallons \\ $87 \%$
}

These figures are based on design estimates. HVAC condensate quantities are based upon design estimates provided by the Mechanical Engineer for the project. The total landscape water required annually a design calculation based upon species, water needs, seasonal changes and evapotranspiration rates. These figures were calculated on a monthly basis and all twelve (12) months were added together in order to come up with the figure above. 
- Reuses up to 250 gallons per day of university well water 'blow off' (backwash from a sand filter well) that was previously sent to a stormwater system.

A sand filter well source adjacent to the project requires frequent backwashing by University Facilities and Maintenance. This procedure occurs $4-5$ days per week and is done manually by staff. Water totaling as much as 250 gallons per occurrence had been historically discharged into a storm drain system. Due to the proximity of this well to the project, water is now re-directed into the wetland pond helping maintain water levels within the pond which supports wetland vegetation and fish habitat.

\section{Other Benefit}

- Sourced all materials and labor from within Arizona, with the exception of various irrigation components and the pond liner.

Nearly every component of the landscape was donated from local sources, suppliers and nursery growers. Donated materials from local sources included inert materials, trees, understory planting, wetland planting and numerous irrigation supplies. Donated labor included all landscape installation related labor, wetland pond construction, low voltage lighting installation, and irrigation installation. 